\title{
Prevalence of Helicobacter pylori among patients with dyspepsia and correlation between endoscopic and histological diagnosis.
}

\author{
KC Shiva Raj', Lakhey A ${ }^{1}$, Koirala K², Amatya GL ${ }^{3}$ \\ ${ }^{I}$ Department of Pathology, KIST Medical College, Lalitpur, Nepal. \\ ${ }^{2}$ Department of Surgery, KIST Medical College, Lalitpur, Nepal. \\ ${ }^{3}$ Department of Gastroenterology, Bir Hospital, Kathmandu,Nepal.
}

\author{
Keywords: \\ Gastritis; \\ Follicular gastrtitis; \\ Carcinoma; \\ Endoscopy; \\ Active gastritis
}

\section{ABSTRACT}

Background: Dyspepsia is a prevalent complaint in general practice and gastrointestinal clinics. Helicobacter pylori have major causal relationship with gastro duodenal disease. The following study seeks to identify the prevalence of $\mathrm{H}$. pylori based on histology and to correlate endoscopic findings with histopathology.

Materials and Methods: This was a cross-sectional observational study conducted in GRP Polyclinic and Om Hospital and research centre from April 2015-September 2015. The upper gastrointestinal endoscopic findings were recorded and were correlated with histopathological findings. All the relevant data were collected and analysed using Statistical Package of Social Sciences version 16 for windows.

Results: Endoscopy finding was divided into reflux esophagitis, antral gastritis, duodenitis, duodenal ulcer, gastric ulcer, and gastric cancer. Duodenal ulcer and gastric ulcer was noted more frequently in males than in females $(55.0 \%$ vs. $45.0 \%$ and $58.2 \%$ vs. $41.8 \%)$, respectively, $\mathrm{P}<0.001)$.

Chronic follicular gastritis was the most common in gastric ulcer (41.7\%), whereas chronic persistent gastritis was common in non-ulcerative disease. Chronic active gastritis and chronic follicular gastritis were more common in ulcerative diseases, whereas chronic persistent gastritis was more common in gastritis and duodenitis $(\mathrm{P}<0.001)$. The overall prevalence of $\mathrm{H}$. pylori infection was $68.1 \%$ with male preponderance. Chronic active gastritis had highest prevalence of $\mathrm{H}$. pylori $(84.8 \%)$, followed by chronic follicular gastritis $(84.1 \%$ ) and chronic persistent gastritis ( $\mathrm{p}$ value $<0.001$.

Conclusion: Rate of H. pylori infected patients with dyspepsia was high. Ulcerative lesions were more common in males than in females with higher rate of infection with H. Pylori. Histological diagnosis of chronic active gastritis and chronic follicular gastritis was the most common pathologies in ulcerative lesions.
Correspondence:

Dr. Shiva Raj K C, MBBS, MD

Department of Pathology

KIST Medical College, Imadole, Laltipur, Nepal

Email:shiva_kc_123@yahoo.com

\section{INTRODUCTION}

Dyspepsia is a prevalent complaint in general practice and gastrointestinal clinics. ${ }^{1}$ Helicobacter pylori (H. pylori) were of major concern today because of its causal relationship with gastro duodenal disease. After the discovery of $\mathrm{H}$. pylori by Marshall and Warren in 1983 by using Warthin Starry Silver stain, the etiological understanding of gastritis 
Table: 1 Prevalence of Helicobacter Pylori in accordance with endoscopic diagnosis

\begin{tabular}{lccc}
\hline Endoscopy & Male no (\%) & Female no (\%) & Overall no (\%) \\
\hline Esophagitis & $20 / 35(57.0)$ & $30 / 67(44.7)$ & $50 / 102(49.0)$ \\
\hline Gastrtitis & $151 / 246(61.3)$ & $222 / 337(65.8)$ & $373 / 583(63.9)$ \\
\hline Duodenitis & $49 / 73(67.1)$ & $27 / 34(79.4)$ & $76 / 107(71.0)$ \\
Gastric Ulcer & $56 / 60(93.3)$ & $34 / 43(79.0)$ & $90 / 103(87.3)$ \\
Duodenal ulcer & $57 / 66(86.3)$ & $45 / 54(83.3)$ & $102 / 120(85.0)$ \\
Gastric carcinoma & $3 / 3(100)$ & $1 / 2(50)$ & $4 / 5(80)$ \\
Total & $\mathbf{3 3 6 / 4 8 3 ( 6 9 . 5 )}$ & $\mathbf{3 5 9 / 5 3 7 ( 6 6 . 8 )}$ & $\mathbf{6 9 5 / 1 0 2 0}(\mathbf{6 8 . 1})$
\end{tabular}

Table: 2 Incidence of Helicobacter Pylori in accordance with endoscopic diagnosis and correlation with histopathology

\begin{tabular}{|c|c|c|c|c|c|c|c|c|c|c|c|c|}
\hline \multirow{2}{*}{ Diagnosis } & \multicolumn{3}{|c|}{ Chronic persistent Gastritis } & \multicolumn{3}{|c|}{ Chronic Active Gastritis } & \multicolumn{3}{|c|}{ Chronic Follicular Gastrtitis } & \multicolumn{3}{|c|}{ Carcinoma } \\
\hline & H.Pylori + & H.Pylori - & Total & H.Pylori + & H.Pylori - & Total & H.Pylori + & H.Pylori - & Total & H.Pylori + & H.Pylori - & Total \\
\hline Esophagitis & $\begin{array}{c}16 / 41 \\
(39.0 \%)\end{array}$ & $\begin{array}{c}25 / 41 \\
(61.0 \%)\end{array}$ & $\begin{array}{c}41 / 102 \\
(40.19 \%)\end{array}$ & $\begin{array}{c}30 / 56 \\
(53.57 \%)\end{array}$ & $\begin{array}{c}26 / 56 \\
(46.42 \%)\end{array}$ & $\begin{array}{c}56 / 102 \\
(54.90 \%)\end{array}$ & $\begin{array}{c}4 / 5 \\
(80 \%)\end{array}$ & $\begin{array}{c}1 / 5 \\
(20 \%)\end{array}$ & $\begin{array}{c}5 / 102 \\
(4.90 \%)\end{array}$ & - & - & - \\
\hline Gastritis & $\begin{array}{l}93 / 251 \\
(37 \%)\end{array}$ & $\begin{array}{l}158 / 251 \\
(62.95 \%)\end{array}$ & $\begin{array}{c}251 / 583 \\
(43 \%)\end{array}$ & $\begin{array}{l}190 / 225 \\
(84.4 \%)\end{array}$ & $\begin{array}{c}35 / 225 \\
(15.5 \%)\end{array}$ & $\begin{array}{l}225 / 583 \\
(38.6 \%)\end{array}$ & $\begin{array}{c}90 / 107 \\
(84.1 \%)\end{array}$ & $\begin{array}{c}17 / 107 \\
(15.8 \%)\end{array}$ & $\begin{array}{l}107 / 583 \\
(18.3 \%)\end{array}$ & - & - & - \\
\hline Duodenitis & $\begin{array}{c}22 / 53 \\
(41.5 \%)\end{array}$ & $\begin{array}{c}31 / 53 \\
(58.5 \%)\end{array}$ & $\begin{array}{c}53 / 107 \\
(49.5 \%)\end{array}$ & $\begin{array}{c}40 / 40 \\
(100 \%)\end{array}$ & $\begin{array}{c}0 / 40 \\
(0.0 \%)\end{array}$ & $\begin{array}{l}40 / 107 \\
(37.3 \%)\end{array}$ & $\begin{array}{c}14 / 14 \\
(100 \%)\end{array}$ & $\begin{array}{c}0 / 14 \\
(0.0 \%)\end{array}$ & $\begin{array}{l}14 / 107 \\
(13.0 \%)\end{array}$ & - & - & $\cdot$ \\
\hline Duodenal Ulcer & $\begin{array}{c}13 / 27 \\
(48.1 \%)\end{array}$ & $\begin{array}{c}14 / 27 \\
(51.8 \%)\end{array}$ & $\begin{array}{l}27 / 120 \\
(22.5 \%)\end{array}$ & $\begin{array}{c}67 / 67 \\
(100 \%)\end{array}$ & $\begin{array}{c}0 / 67 \\
(0.0 \%)\end{array}$ & $\begin{array}{l}67 / 120 \\
(62.6 \%)\end{array}$ & $\begin{array}{c}22 / 26 \\
(84.6 \%)\end{array}$ & $\begin{array}{c}4 / 26 \\
(15.3 \%\}\end{array}$ & $\begin{array}{l}26 / 120 \\
(21.6 \%)\end{array}$ & - & - & - \\
\hline Gastric Ulcer & $\begin{array}{c}18 / 18 \\
(100 \%)\end{array}$ & $\begin{array}{c}0 / 18 \\
(0.0 \%)\end{array}$ & $\begin{array}{c}18 / 103 \\
(17.4 \%)\end{array}$ & $\begin{array}{c}38 / 42 \\
(90.4 \%)\end{array}$ & $\begin{array}{c}4 / 42 \\
(9.5 \%)\end{array}$ & $\begin{array}{l}42 / 103 \\
(40.7 \%)\end{array}$ & $\begin{array}{c}34 / 43 \\
(79.0 \%)\end{array}$ & $\begin{array}{c}9 / 43 \\
(20.9 \%)\end{array}$ & $\begin{array}{l}43 / 103 \\
(41.7 \%)\end{array}$ & - & - & - \\
\hline Carcinoma & - & - & - & - & - & - & - & - & - & $4 / 5(80.0 \%)$ & $1 / 5(20.0 \%)$ & $\begin{array}{c}5 / 5 \\
(100.0 \%)\end{array}$ \\
\hline Total & $\begin{array}{l}162 / 390 \\
(41.5 \%)\end{array}$ & $\begin{array}{l}228 / 390 \\
(58.4 \%)\end{array}$ & $\begin{array}{l}390 / 1020 \\
(38.2 \%)\end{array}$ & $\begin{array}{l}365 / 430 \\
(84.8 \%)\end{array}$ & $\begin{array}{c}65 / 430 \\
(15.1 \%)\end{array}$ & $\begin{array}{l}430 / 1020 \\
(42.1 \%)\end{array}$ & $\begin{array}{l}164 / 195 \\
(84.1 \%)\end{array}$ & $\begin{array}{l}31 / 195 \\
(15.9 \%)\end{array}$ & $\begin{array}{c}195 / 1020 \\
(19.1 \%)\end{array}$ & $\begin{array}{c}4 / 5 \\
(80.0 \%)\end{array}$ & $\begin{array}{c}1 / 5 \\
(20.0 \%)\end{array}$ & $\begin{array}{c}5 / 5 \\
(100.0 \%)\end{array}$ \\
\hline
\end{tabular}

and its role as bacterial carcinogen have changed the management of gastritis. One half of the world's population has $\mathrm{H}$. pylori infection, with an estimated prevalence of more than $90 \%$ in developing countries. ${ }^{2-6}$ In our country, the reported prevalence of $\mathrm{H}$. pylori ranged from $30 \%$ to $67 \% .^{7-11}$ This bacterium colonizes human gastric mucosa and can elicit lifelong inflammatory and immune responses, with release of various bacterial and host dependent cytotoxic substances. It causes chronic and active gastritis, peptic ulcer disease and associated with increased risk of developing gastric cancer. ${ }^{12-14}$

The following study seeks to identify the prevalence of $\mathrm{H}$. pylori based on histology and to correlate endoscopic findings with histopathology.

\section{MATERIAL AND METHODS}

This was an observational cross-sectional study at GRP Polyclinic Pvt. Ltd and Om Hospital and Research centre Pvt Ltd over a period of 6 months from from April 2015-September 2015. Data analysis was done from all consecutive individuals who had undergone gastric biopsy during upper GI endoscopy for various dyspeptic symptoms like pain abdomen, nausea, vomiting, belching, throat pain, upper gastrointestinal bleeding, weight loss etc. However, patients under the age of 14 years, with oesophageal varices were not included in the study. Prior to investigation, informed consent was taken from the patient. Permission from ethical review committee was obtained.

The upper gastrointestinal endoscopy was performed by two physicians separately and endoscopic findings were categorized into gastro-esohageal reflux disease, antral gastritis, gastric ulcer, duodenitis, duodenal ulcer, and neoplasm. The biopsy specimens were usually taken from the gastroesophageal junction, antrum or duodenum depending upon the endoscopic findings and sent for histological examination. The biopsy specimens were fixed in $10 \%$ buffered formalin, processed, embedded in paraffin, and cut and stained with Hematoxylin and Eosin (HandE) and Giemsa stain. Histological reporting was done by pathologist using Modified Sidney system which included inflammation, activity, atrophy, intestinal metaplasia, and Helicobacter Pylori colonization. ${ }^{15}$ Histologically, gastritis was classified into chronic active gastritis (CAG), chronic follicular gastritis (CFG), and chronic persistent gastritis (CPG) with or without intestinal metaplasia, atrophy and Helicobacter Pylori colonization.

All the relevant data were collected and analysed using using Statistical Package of Social Sciences (SPSS) version 16 for windows. Chi-square test with exact test was used where applicable. P values of $<0.05$ were considered to denote statistical significance. 


\section{RESULTS}

TA total of 1020 UGI endoscopies were performed and biopsies were taken during the study period. The age of the patients ranged from 16-94 years with the mean of 41.7 \pm 18 . Among all the patients, $549(53.8 \%)$ were females and $471(46.1 \%)$ were males.

Endoscopy finding was divided into reflux esophagitis, antral gastritis, duodenitis, duodenal ulcer, gastric ulcer, and gastric cancer, which was diagnosed in $102(10.0 \%)$, $583(57.1 \%), 107$ (10.5\%), 120 (11.7\%), 103 (10.0\%), and $5(0.5 \%)$ patients, respectively. Duodenal ulcer and gastric ulcer was noted more frequently in males than in females (n $=66 ; 55.0 \%$ vs. $\mathrm{n}=54 ; 45.0 \%$ and $\mathrm{n}=60 ; 58.2 \%$ vs. $\mathrm{n}=43$; $41.8 \%$ ), respectively, $\mathrm{P}<0.001)$. In contrast, Esophagitis, antral gastritis was more common among females $(n=67$; $65.6 \%$ vs. $\mathrm{n}=35 ; 34.4 \%$ and $\mathrm{n}=337 ; 57.8 \%$ vs. $\mathrm{n}=246$; $42.2 \%$ ) respectively.

The histological features were divided into chronic persistent gastritis (CPG), chronic active gastritis (CAG), chronic follicular gastritis (CFG), and gastric carcinoma which were detected in $390(38.2 \%), 430(42.1 \%), 195$ $(19.1 \%)$, and $5(0.5 \%)$ of cases respectively. CAG was the frequent finding in those who had duodenal ulcer $(n=67$; $62.6 \%$ ), all of which (100\%) were colonized with H. pylori followed by gastric ulcer $(n=42 ; 40.7 \%)$. CFG was most common in gastric ulcer $(\mathrm{n}=43 ; 41.7 \%)$, whereas $\mathrm{CPG}$ was common in non-ulcerative disease (duodenitis $-\mathrm{n}=$ 53; 49.5\%; and gastritis $-\mathrm{n}=251 ; 43 \%$ ). CAG and $\mathrm{CFG}$ were more common in ulcerative diseases, whereas $\mathrm{CPG}$ was more common in gastritis and duodenitis $(\mathrm{P}<0.001)$. Those who had histological features of CAG had highest prevalence of $\mathrm{H}$. pylori $(\mathrm{n}=365 ; 84.8 \%$ ), followed by $\mathrm{CFG}$ $(\mathrm{n}=164 ; 84.1 \%)$ and $\mathrm{CPG}(\mathrm{n}=162 ; 41.5 \%)$ with $\mathrm{P}$ value $<0.001$.

The overall prevalence of $\mathrm{H}$. pylori infection was $695 / 1020$ $(68.1 \%)$ with male preponderance; Male: $69.5 \%$ vs. F: $66.8 \%$ (Table 1). Helicobacter Pylori was found in 50 $(49.0 \%)$ cases of esophagitis, $373(63.9 \%)$ cases of antral gastritis, 76 cases $(71.0 \%)$ of duodenitis, $102(85.0 \%)$ cases of duodenal ulcer, 90 cases $(87.3 \%)$ of gastric ulcer, and 4 cases $(80 \%)$ of gastric carcinoma. In gastric ulcer and duodenal ulcer including gastric carcinoma there was significantly higher prevalence of $\mathrm{H}$. pylori $(\mathrm{P}=0.046)$; however, no significant difference in the prevalence of H. pylori was observed between esophagitis, gastritis and duodenitis. The colonization rate of $\mathrm{H}$. pylori in relation to different endoscopy diagnosis is illustrated in Table 1.

Intestinal metaplasia was identified in 3\% (31/1020) of the patients who underwent UGI endoscopy. Only 11 (35.4\%) patients with intestinal metaplasia had colonization by Helicobacter Pylori. The mean age of the patient with intestinal metaplasia was $54.2 \pm 16.9$ years. There was significant male predominance with male to female ratio of 1.6:1.

Atrophy was noted in 24(2.35\%) of all the patients included in this study. There was female predominance male to female ratio of $0.7: 1$. The mean age of the patient with atrophic gastritis was $40.8 \pm 12.6$.

\section{DISCUSSION}

Current standard of care for most patients with symptoms of upper GIT consists of initial endoscopic examination followed by histopathology. The individual accuracy and sensitivity of these techniques in the diagnosis of any lesions is subjective to the operator's ability to target site of pathology. Helicobacter Pylori remains the most common cause of chronic gastritis. Furthermore, since Helicobacter pylorus has carcinogenic effect, it has radically changed our understanding and clinical management of gastroduodenal disease, and much has been researched about its clinical aspects and its epidemiology. ${ }^{16}$

In this study age of the patients with dyspepsia ranged from 16-94 years with the mean of 41.7 years. Among the patients seeking for medical help due to dyspepsia 549 (53.8\%) were female and 471(46.1\%) were male with slight female predominance (M:F- 1:1.16). A study done by Sharma et al documented $51 \%$ female seeking for medical help due to dyspepsia as compared to $49 \%$ males. $^{17}$

Most common upper gastrointestinal endoscopic findings were antral gastritis $57.1 \%$ ) followed by duodenal ulcer $(11.7 \%)$, duodenitis $(10.5 \%)$ and gastric ulcer $(10.0 \%)$ Similar finding was observed in a study done by Poudel A et al. He observed $58.1 \%$ cases had antral gastritis followed by $11.63 \%$ with peptic ulcer. ${ }^{18}$ Reflux esophagitis was observed in $10 \%$ of the patients which was less than study conducted by Ercelep OB et al. ${ }^{19}$ Ulcerative lesions of stomach and duodenum was more common in males than in females as was observed in a study done by Shrestha $\mathrm{R}$ et al. ${ }^{20}$

Most common pathology in histopathology was chronic active gastritis $(42.1 \%)$, followed by chronic persistent gastritis (38.2\%), chronic follicular gastritis (19.1\%) and gastric carcinoma $(0.5 \%)$. This result was in concordance with other study. ${ }^{20}$ In ulcerative lesions most common antral biopsy finding was chronic active gastritis and chronic follicular gastritis whereas in non-ulcerative lesions chronic persistent gastritis was the commonest diagnosis. Patients with chronic active gastritis and chronic follicular gastritis had higher frequency of Helicobacter Pylori positivity with incidence of $84.8 \%$ and $84.1 \%$ respectively. Higher incidence of Helicobacter Pylori were also seen in other studies done by Shrestha $\mathrm{R}$ et al. ${ }^{20}$ Other studies also identified association between ulcerative lesions and higher incidence of Helicobacter Pylori. ${ }^{21-23}$ Study done by X Y Chen et al observed positive correlation with the prevalence 
and density of lymphoid follicles and aggregates with $\mathrm{H}$ pylori infection. ${ }^{24}$ In a study done by Genta $\mathrm{RM}$ et $\mathrm{a}^{25}$ observed $100 \%$ presence of Helicobacter Pylori in patients with chronic follicular gastritis. These discrepancies may be due to: 1) Various biopsy sites, 2) intake of proton pump inhibitor which leads to subepithelial colonization of bacteria and is difficult to identify in routine histopathology procedure. Overall prevalence of $\mathrm{H}$. Pylori infection was $68.1 \%$. Overall, researchers found a consistent pattern in most developing nations, where 70 to $90 \%$ of adults harbored the bacteria; most individuals acquired the infection as children, before age ten. ${ }^{5,6}$ Nepalese data show that the prevalence of $\mathrm{H}$. pylori infection varies widely from $30-67 \%{ }^{6-11}$

Intestinal metaplasia was observed in $3 \%(n=31)$ of the dyspeptic patients whereas gastric atrophy was noted in $3.25 \%(\mathrm{n}=24)$ patients. Gastric carcinoma was seen in $5(0.5 \%)$ of cases with $80 \%$ having Helicobacter Pylori infection. The data is too small to compare with other studies.

\section{CONCLUSION}

Rate of $\mathrm{H}$. pylori infected patients with dyspepsia was high. Ulcerative lesions were more common in males than in females with higher rate of infection with $\mathrm{H}$. Pylori. detected by histopathology among adult patients with gastrointestinal symptoms was high (68\%). Histological diagnosis of chronic active gastritis and chronic follicular gastritis was the most common pathologies in ulcerative lesions. Because of higher prevalence rate of H. Pylori; routine endoscopic biopsy should be performed so as to detect this gram negative microorganism and to treat accordingly.

\section{REFERENCES}

1. Sobieraj, D.M., Coleman, S.M. and Coleman, C.I. (2011) US Prevalence of Upper Gastrointestinal Symptoms: A Systematic Literature Review. American Journal of Managed Care 2011;17:44958.

2. Go MF. Natural history and epidemiology of Helicobacter pylori infection. Aliment Pharmacol Ther 2002;16:3-15. Crossref

3. Megraud F. Epidemiology of Helicobacter pylori infection. In: Rathbone BK, Heatley RV, editors.Helicobacter pylori and gastroduodenal disease. London: Blackwell Scientific Publication; 1993. pp.107-23.

4. Veldhuyzen van zantel SJ. Do socioeconimicstatus, marital status and occupation influence the prevalence of Helicobacter pylori infection? Aliment Pharmacol Ther.1995;9:41-4.

5. Hunt RH, Xiao SD, Megraud F, Leon-Barua R, et al. Helicobacter pylori in developing countries. World Gastroenterology Organisation
Global Guidelines; World Gastroenterology Organization. J Gastrointestin Liver Dis. 2011;20:299-304. Crossref

6. Lacy BE, Rosemore J. Helicobacter pylori: Ulcers and more: The beginning of an era. J Nutr.2001;131:27895-935. [PubMed]

7. Rai SK, Shah RD, Bhattachan CL, Rai CK, Ishiyama S, Kurokawa $\mathrm{M}$, et al. Helicobacter pylori associated gastroduodenal problem among the Nepalese. Nepal Med Coll J. 2006;8:9-13. Crossref

8. Makaju R, Tamang MD, Sharma Y, et al. Comparative study on a homemade rapid urease test with gastric biopsy for diagnosis of Helicobacter pylori infection. Nepal Med Coll J. 2006;8:97-100. Crossref

9. Makaju RK, Tamang MD, Sharma Y, Sharma N, Koju R, Ashraf M. Prevalence of Helicobacter pylori in Dhulikhel Hospital, Kathmandu University Teaching Hospital: A retrospective histopathologic study. Kathmandu Univ Med J 2005;3:355-9.

10. Khanal S, Rao BS, Sharma Y, Khan GM, Makaju R. Comparative study between two triple therapy regimens on eradication of Helicobacter pylori. Kathmandu Univ J Sci Engg Technol. 2005:110 .

11. Kawasaki M, Kawasaki T, Ogaki T, et al. Seroprevalence of Helicobacter pylori infection in Nepal: Low prevalence in an isolated rural village. Eur J Gastroenterol Hepatol. 1998;10:47-50. Crossref

12. Roussos, A., Philippou, N. and Gourgoulianis, K.I.Helicobacter pylori Infection and Respiratory Diseases: A Review. World J Gastroenterol 2003;9: 5-8. Crossref

13. Jia, E.Z., Zhao, F.J., Hao, B., et al. Helicobacter pylori Infection Is Associated with Decreased Serum Levels of High Density Lipoprotein, but Not with the Severity of Coronary Atherosclerosis. Lipids in Health and Disease, 2009;23:59. Crossref

14. Atherton, J.The Pathogenesis of H. pylori Induced Gastro-Duodenal Diseases. Annual Review of Pathology: Mechanisms of Disease 2006;1:63-96. Crossref

15. Price AB. The sydney system. Histological division. J Gastroenterol Hepatol. 1991;6:209-22. Crossref

16. Suk F, Lien G, Yu T, Ho Y. Global trends in Helicobacter pylori research from 1991-2008 analyzed with the Science Citation Index Expanded. Eur J Gastroenterol Hepatol. 2011;23:295-301. Crossref

17. Sharma SK, Maharjan DK, Thapa PB. Hospital based analytic study of peptic ulcer disease in patients with dyspeptic symptoms. Kathmandu Univ Med J 2009;7:135-8.

18. Poudel A., Regmi S., Poudel S., Joshi P. Correlation between endoscopic and histopathological findings in gastric lesions. Journal of Universal College of Medical Sciences 2013;1: 37-41. Crossref 
19. Ereelep OB, Caglar E, Dobrucali A. The prevalence of gastroesophageal reflux disease among hospital employees. Dis Esophagus. 2014;27:403-8. Crossref

20. Shrestha R, Koirala K, K C Shiva Raj, Hada Batajoo K. Helicobacter Pylori Infection Among Patients with Upper Gastrointestinal Symptoms: Prevalence and Relation to Endoscopy Diagnosis and Histopathology. J Family Med Prim Care. 2014;3:154-8. Crossref

21. Dixon MF. Helicobacter pylori and peptic ulceration: Histopathological aspects. J Gastroenterol Hepatol. 1991;6:125-30. http://dx.doi.org/10.1111/j.1440-1746.1991.tb01451.x

22. Zhang C, Yamada N, Wu YL, Wen M, Matsuhisa T, Matsukura N. Comparison of Helicobacter pylori infection and gastric mucosal histological features of gastric ulcer patients with chronic gastritis patients. World J Gastroenterol. 2005;11:976-81. Crossref
23. Chan WY, Hui PK, Leung KM. Coccoid forms of Helicobacter pylori in human stomach. Am J Clin Pathol. 1994;102:503-7. Crossref

24. Chen X Y, Liu WZ, Shi Y, Zhang DZ, Xiao SD, Tytgat GNJ. Helicobacter pylori associated gastric diseases and lymphoid tissue hyperplasia in gastric antral mucosa. J Clin Pathol. 2002;55:133-7. Crossref

25. Genta RM, Hammer HW. The significance of lymphoid follicles in the interpretation of gastric biopsy specimens. Arch Pathol Lab Med 1994;118:740-3. Crossref 